\title{
Dendroecological investigations at Venner Moor (northwest Germany) document climate-driven woodland dynamics and mire development in the period 2450-2050 BC
}

\author{
Jan Eckstein, ${ }^{1 *}$ Hanns Hubert Leuschner, ${ }^{1}$ Thomas Giesecke, ${ }^{1}$ \\ Lyudmila Shumilovskikh ${ }^{1}$ and Andreas Bauerochse ${ }^{2}$
}

\author{
(' University of Goettingen, Albrecht-von-Haller-Institute, Department of Palynology and Climate \\ Dynamics, Untere Karspüle 2, 37073 Goettingen, Germany; ${ }^{2}$ Lower Saxony State Service for Cultural \\ Heritage, Scharnhorststraße 1, 30175 Hannover, Germany)
}

Received 30 June 2009; revised manuscript accepted 8 September 2009

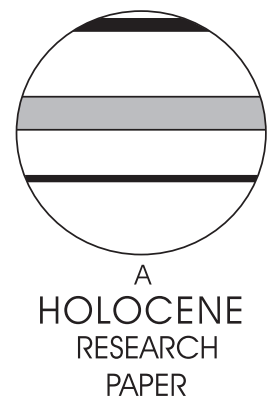

\begin{abstract}
Excellently preserved subfossil pine and oak tree remains from the bottom layer of raised bog peat were dendroecologically investigated at Venner Moor (northwest Germany). Tree-ring analyses were combined with observations of stem and root morphology, preservation state, mineral soil relief, peat stratigraphy and pollen analysis to reconstruct in great detail environmental changes leading to the start of the raised bog formation. Hydrology was identified as the main determinant influencing tree growth and population dynamics at Venner Moor, as documented by different growth patterns and dying-off dates in relation to the mineral soil elevation. The woodland phase has been dendrochronological dated to the period from 2421-2077 BC (4371-4027 cal BP). In this period, a general change from more or less open landscape with dominating heath to wet pine forest and eventually to open raised bog occurred at the site. Comparisons with pine population dynamics at the nearby Voerdener Moor and with the independent Lower Saxony Bog Oak Chronology (LSBOC) indicate that the reconstructed ecological changes at Venner Moor are mainly triggered by climate variations, in particular wet shifts on the decadal timescale. This example shows the value of subfossil pine layers from northwest German bogs as a high resolution proxy archive of Holocene humidity fluctuations.
\end{abstract}

Key words: Dendroecology, fen-bog transition, Holocene, palaeoclimate, Scots pine.

\section{Introduction}

Subfossil wood buried under peat, at the bottom of lakes or covered by soil or glacial deposits, is one of the best archives of Holocene environmental changes due to the precise dating opportunity and annual resolution. In northwest Germany, subfossil oaks from mire habitats were extensively studied dendrochronologically during the last few decades (Leuschner et al., 1985, $1987,2002)$ and subfossil pines have become the focus of more recent investigations (Bauerochse et al., 2006; Leuschner et al., 2007; Eckstein et al., 2009). As a result some 1700 oaks and 800 pines were dated. The most striking feature of this large data is

*Author for correspondence (e-mail: jan.eckstein@biologie.uni-goettingen.de)

(C) The Author(s), 2010. Reprints and permissions: http://www.sagepub. co.uk/journalsPermissions.nav a step-wise temporal distribution of the tree samples. This shows that the population dynamics is characterised by distinct woodland generations separated by more or less sharp germination and dying-off (GDO) phases. Based on the data on sub-fossil oaks, Leuschner et al. (2002) concluded that population dynamics is most likely related to climate, since GDO phases, as well as centennial-scale tree-ring width (TRW) variations, are often synchronous over large areas. The subfossil pines from northwest Germany show a similar step-wise temporal distribution as found in oaks, but have more abrupt GDO phases. Population dynamics of the subfossil pines is often synchronous with abrupt TRW changes in the Lower Saxony bog oak chronology (LSBOC), which also contains a climate signal (Leuschner et al., 2007; Bauerochse et al., 2008). However, it is not yet fully understood 
which ecological changes were responsible for the observed abrupt GDO phases. We hypothesise that hydrology is the main factor influencing tree growth and population dynamics, since the subfossil trees originate from mire habitats. However, a detailed reconstruction of past site conditions and changes were in most cases impossible, since the great majority of the samples were found ex situ, i.e. relations to the peat stratigraphy and differences between individual trees were unknown.

At Venner Moor (district Osnabrueck, Lower Saxony, Germany), we investigated a subfossil pine and oak woodland in detail. Due to the peat harvesting method we were able to study the well preserved and fully accessible tree remains in situ and relate their position to variations in the mineral soil relief. This opens the possibility to reconstruct the temporal and spatial development of the woodland in relation to mineral soil elevation and water table changes. Thus, the study site at Venner Moor is ideally suited to test the hypothesis that tree growth variability and population dynamics of subfossil trees from lowland peatlands represent a hydrological record.

In following this general theme, this study aims to answer the following three questions: (i) which changes in site conditions can be inferred from the assemblage of information available and when did they occur at Venner Moor? (ii) is hydrology indeed the main ecological site factor influencing growth and population dynamics of the trees? and (iii) Are changes in site conditions local effects or in tune with regional changes? In pursuit of answers to these questions, multi-proxy investigations were undertaken including: dendrochronology, stem and root morphology, preservation state of the wood remains, as well as peat stratigraphy and pollen analysis (Bauerochse et al., 2008).

\section{Site description}

The study site Venner Moor $\left(52.44^{\circ} \mathrm{N}\right.$ and $\left.8.17^{\circ} \mathrm{E}\right)$ is part of the Duemmer basin, a major peatland area situated in the southern part of the northwest German lowlands (Figure 1). The climate can be described as transitional, between oceanic conditions in the northwest and a more continental climate in the east. Annual mean temperature of $8.9^{\circ} \mathrm{C}$ and a mean annual precipitation of $695 \mathrm{~mm}$ are reported by the nearest meteorological station Diepholz, $22 \mathrm{~km}$ to the northeast (DWD, 2008).

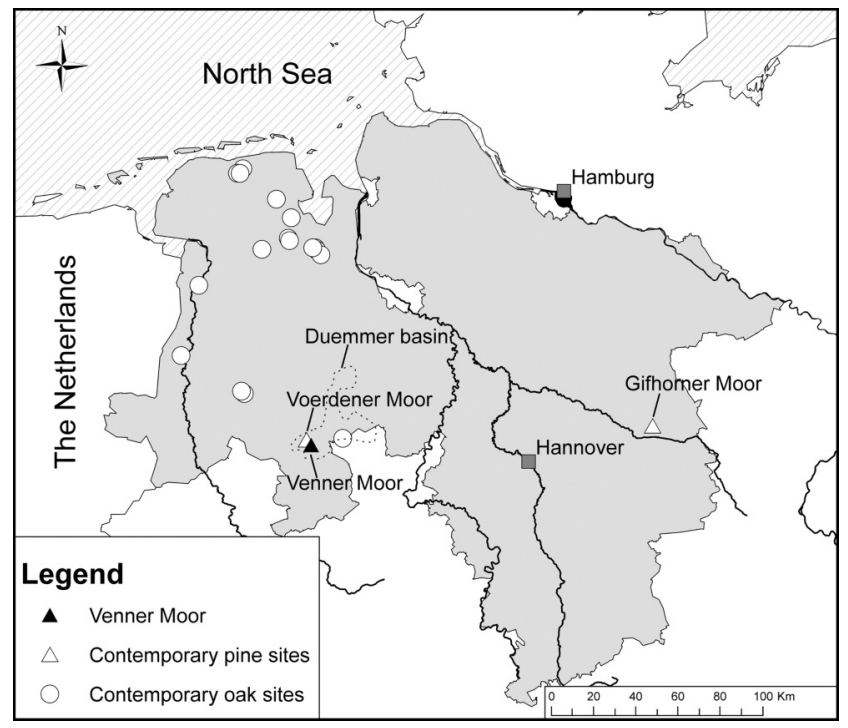

Figure 1 Map of Lower Saxony (grey) in northwest Germany, indicating the position of Venner Moor and of the other study sites with contemporary subfossil trees
Tree stumps and trunks were exposed during peat harvesting at Venner Moor (Figure 2). The peat was removed between the tree remains with an excavator partly down to the mineral soil. The trunks and stumps of the former woodland remained at the site. Deep rooted stumps remained in situ and only smaller trees with shallow root systems were displaced. The excavation took place in two parallel bands of c. $300 \times 30 \mathrm{~m}$, oriented roughly NNE-SSW and $\sim 70 \mathrm{~m}$ apart. The western band yielded the majority of samples $(88 \%)$, exhibits diverse site conditions and is therefore discussed in detail. However, the samples from the eastern band $(12 \%$ of total samples) are included in the analysis of tree-ring data.

\section{Stratigraphy}

The mineral soil in the study area consists of fluvio-glacial sand and morainic material with boulders up to $1 \mathrm{~m}$ in diameter. Between 10 and $40 \mathrm{~cm}$ below the mineral soil surface the sand is red-brown coloured indicating podzolisation. The thickness and sequence of individual peat layers varies in the study area, depending on the mineral soil relief. A minerogenic island that rises up to $1.6 \mathrm{~m}$ above the surrounding area is situated in the middle of the study area (Figure 3). From its highest elevation (45.3 $\mathrm{m}$ a.s.1.) the minerogenic island descends sharply to $43.9 \mathrm{~m}$ a.s.1. at the northern edge and gradually to $44.4 \mathrm{~m}$ a.s.l. at the southern edge. The mineral soil is covered by a layer of black, highly humified peat with no visible macroremains. This layer is up to $20 \mathrm{~cm}$ thick at the northern and southern ends of the study area, then becomes gradually thinner to the middle and is totally missing in the central parts with the highest elevations of the mineral soil. This highly humified layer is superseded by a layer of Eriophorum-peat with pine roots and stumps occasionally accompanied by birch wood. The Eriophorum-peat layer is thickest at the northern and southern edges of the study area. In the central area, with high mineral soil elevations, this layer is thinner and partially contains root remains of sedges (Carex). Above the Eriophorum-peat, there is a layer of less humified Sphagnum-peat, occasionally with small bands of Eriophorum. This layer is up to $65 \mathrm{~cm}$ in places with low mineral soil elevation and becomes gradually thinner and eventually vanishes towards the central part of the study area. It follows a Sphagnum-peat of medium humification, which covers the whole study area. Approximately $2 \mathrm{~m}$ of peat had been harvested above the ground surface, as illustrated in Figure 3.

Most of the subfossil tree remains came from Scots pine (Pinus sylvestris L.) and were found throughout the study site. Oak (Quercus sp.) remains were observed only to the north end of the minerogenic island (Figure 3, peat stratigraphy). Alder (Alnus sp.), birch (Betula sp.) and poplar (Populus sp.) remains were also encountered, although in lower abundances. While birch remains occurred scattered over the whole study site, alder as well as poplar were only sporadically observed in the northern part of the study site (Figure 3 ). Of the encountered tree species, only pine and oak remains were well enough preserved to allow dendrochronological analyses. Oaks were mainly encountered as lying trunks without preserved root systems. In contrast, pines were generally found as stumps with more or less completely preserved root systems. The root plate of the subfossil pine stumps was generally situated in the Eriophorum-peat layer, whereas the remaining stem parts were embedded in the successive Sphagnum-peat. Fallen, broken-off pine trunks were also sometimes preserved in addition to in situ stumps, particularly in parts of the site with higher mineral soil elevation.

\section{Material and methods}

\section{Sampling and surveying}

About $60 \%$ of the pine and $90 \%$ of the preserved oak trunks and stumps were sampled. We aimed to sample trees from the whole 


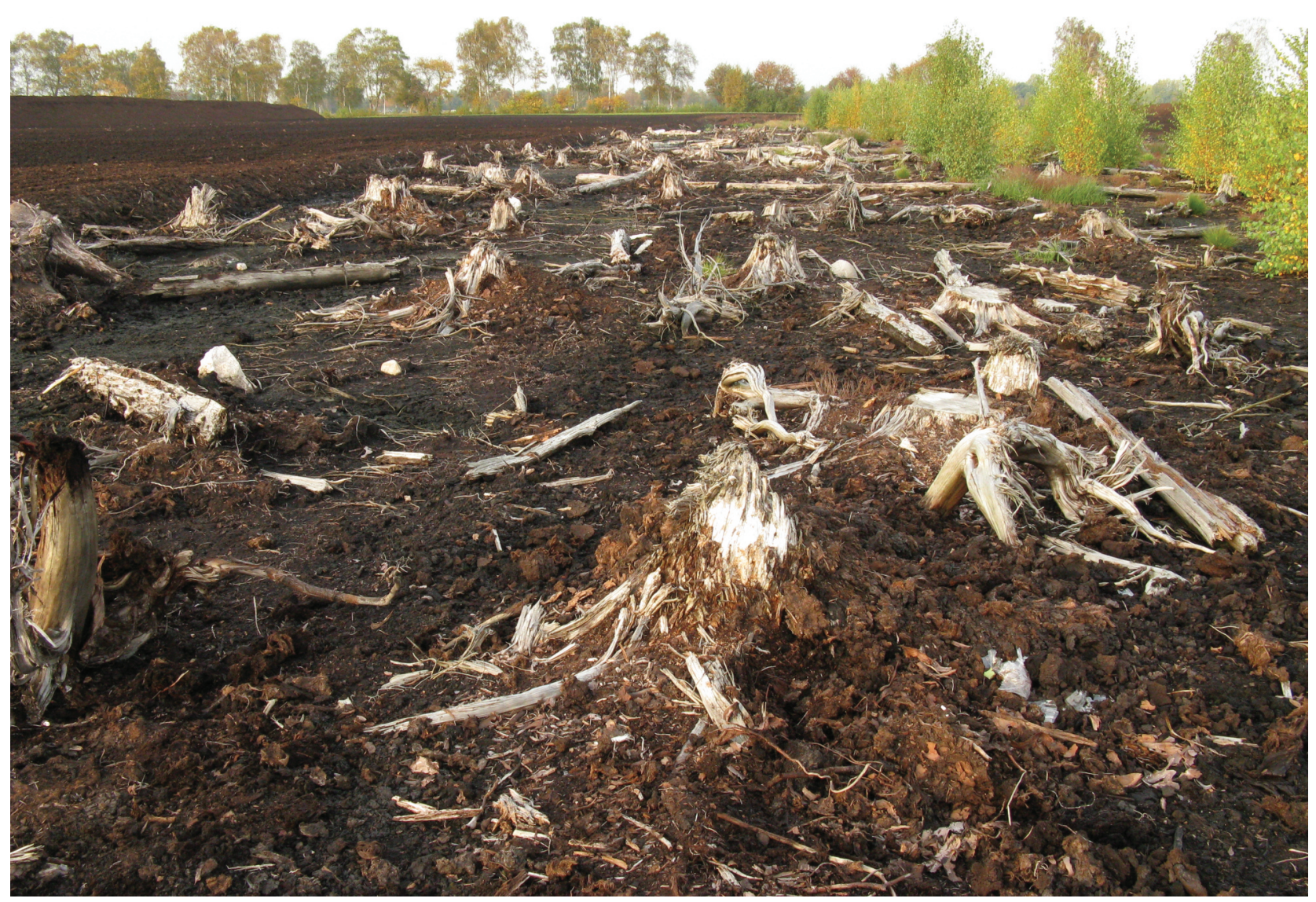

Figure 2 Photograph of the sample site at Venner Moor looking to the north, showing many in situ pine stumps in the middle, more elevated part of the study area

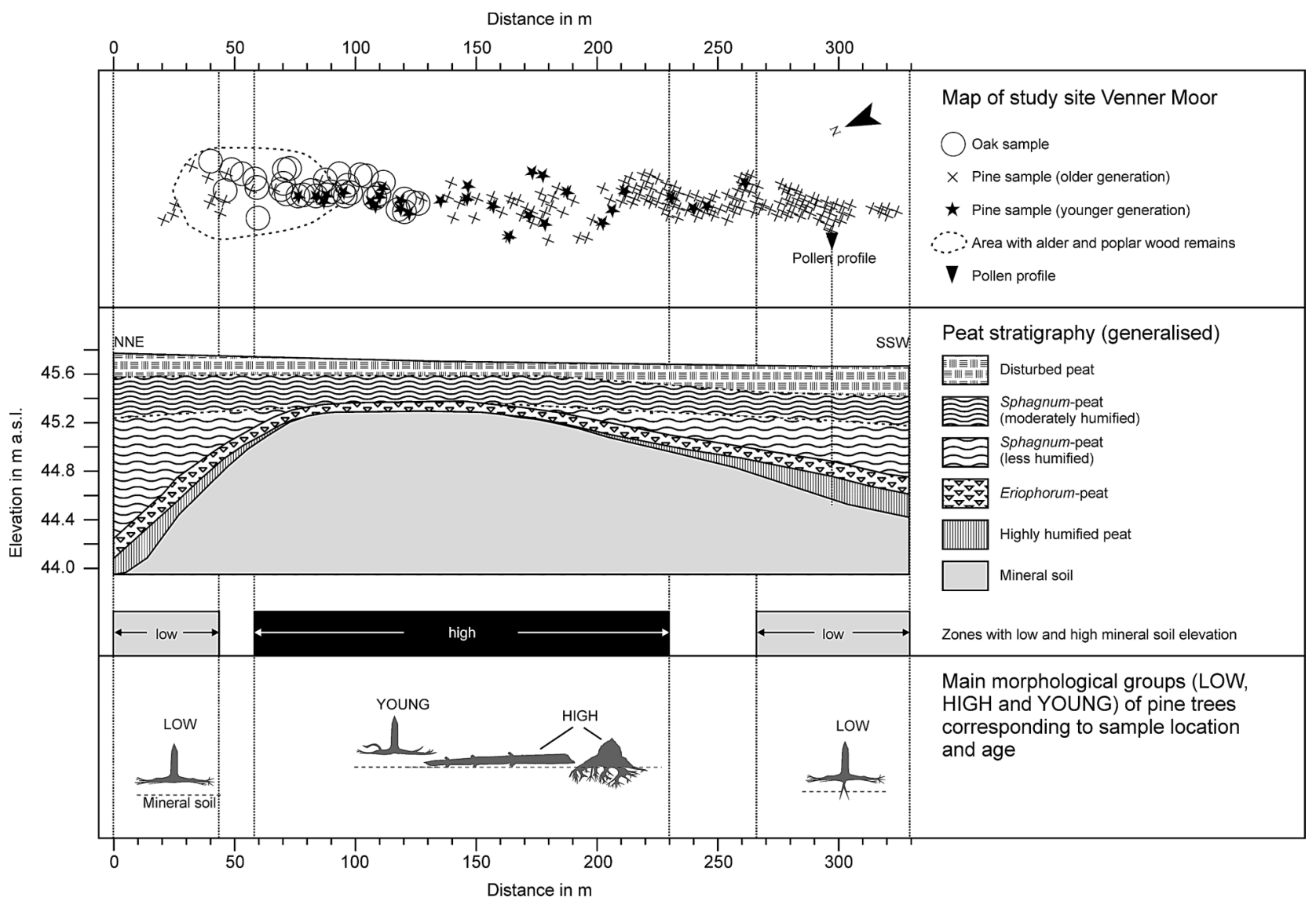

Figure 3 First box - plan view map of the Venner Moor study site. Second box - generalised peat stratigraphy ( $\sim 30$ times super-elevated). Third box main morphological groups of pine tree remains corresponding to areas with high and low mineral soil elevation and to the two pine generations 
site in an even spatial distribution and to gather stem disks from pines that comprised different stem and root morphology. Trees with less than c. 30 rings (as noticed in the field after disk cutting) were considered impossible to crossdate and therefore not sampled. Disks were taken with a chain saw, preferably $\sim 10 \mathrm{~cm}$ above the root plate, in order to get as many rings as possible and to determine the germination date accurately. In some cases we sampled both, the stem as well as the primary root (directly beneath the root plate), in order to determine the root growth within the tree's lifetime. During fieldwork, the geographical position of each sample was obtained using a handheld GPS device. The mineral soil relief was measured along the length of the excavation area at intervals of $1-3 \mathrm{~m}$, using a reflectorless total station (Leica TCR407 Power 7"). A digital terrain model was built from the elevation measurements using ArcGIS 9.1 software. The mineral soil elevation for each location was established by superimposing the sample location onto the digital terrain model.

\section{Dendrochronological methods}

Dendrochronological investigation followed standard procedures (Baillie, 1982; Schweingruber, 1987; Leuschner, 1994). While the sample was still wet, radial sections were cut from the disks and the surface was prepared with surgical and razor blades (Iseli and Schweingruber, 1989; Leuschner and Schweingruber, 1996). After drying, chalk dust was applied to the cross-sections to fill the cell lumina and enhance the visibility of the cell morphology and tree-ring boundaries. In $\sim 90 \%$ of the samples, one radius was measured. In the remaining cases, two or more radii were measured and a tree mean curve was prepared to represent the tree. TRW was measured to the nearest $1 / 100 \mathrm{~mm}$ using a semi-automatic measuring stage (type Aniol) and the program CATRAS (Aniol, 1983). Each tree-ring series was crossdated with all other series respectively with the developing site chronology using the statistical approach of Baillie and Pilcher (1973). Matches, with $t$-values higher than 4.5, were approved or discarded after visual inspection. About $8 \%$ of the pine tree-ring series were corrected for 1-4 missing rings. No missing rings were encountered in the oak tree-ring series. A more detailed description of the procedures for crossdating and chronology building applied to the pine material is given by Eckstein et al. (2009).

The pith was preserved in most cases, whereas the sapwood of some pines and all but one oak had decayed. The number of missing sapwood rings in pines was estimated through comparison with completely preserved samples from the same site with similar age and growth pattern. These were in the range of $30-50 \pm 15$ rings. In oaks we used an estimate of $25 \pm 10$ sapwood rings, which is based on expert knowledge about several hundred bog oaks from northwest Germany. The year of germination was estimated by adding 1 year for every $10 \mathrm{~cm}$ that the disc was cut above the root plate. The measured ring widths were logarithmically transformed and filtered using a dynamically weighted moving average (Riemer, 1994; Leuschner et al., 2002) with a mean length of 100 years. In this manner the age trend is removed and long-term decadal growth variations are preserved.

\section{Pollen analysis}

A $63 \mathrm{~cm}$ long peat monolith of $6 \times 5 \mathrm{~cm}$ was taken for pollen analysis. The location at the southern end of the study area (Figure 3 ) was selected, as it represents an area with a high density of pine tree remains and sufficient peat thickness. Subsamples of $1 \mathrm{~cm}^{3}$ were taken from the profile and prepared for pollen analysis following the protocols of Erdtmann (1960) and Moore et al. (1991), using $\mathrm{KOH}$ treatment and acetolysis. The samples were sieved in an ultrasonic bath at $50 \mathrm{kHz}$ on a $6 \mu \mathrm{m}$ mesh and stored in glycerine. Tablets with a known number of Lycopodium spores were added to determine the concentration of pollen and charcoal particles. Pollen identifications and counts were carried out with $400 \times$, in some cases with $1000 \times$ magnification and an average of 500 pollen grains of trees and shrubs were counted per sample. All frequencies are calculated as percentages of the total sum of terrestrial pollen excluding Ericaceae and Melampyrum pollen, which dominated individual samples. Identification and nomenclature of pollen is based on Beug (2004) and of non-pollen palynomorphs (NPPs) on van Geel et al. (2003) and van Geel and Aptroot (2006).

\section{Results}

\section{Dating of pine and oak}

In total, 263 pine and 53 oak samples were dendrochronologically investigated. Main statistical features of the tree-ring series (TRS) are given in Table 1 . About $85 \%$ of the pine samples and all oak samples could be dendrochronologically synchronised, forming two species chronologies for the site. The Venner Moor oak site chronology (VENMO OAK) was dated with reference to the LSBOC to the period from 2421-2180 BC (overlap $=242$ years, cross-correlation $[\mathrm{CC}]=0.43, t$-value $=7.3)$. The dating of the Venner Moor pine chronology (VENMO PINE) succeeded as part of an ongoing programme to develop a long-term subfossil northwest German pine chronology. A combined chronology of 3 sites (Venner, Voerdener and Gifhorner moors, Figure 1) was dated with reference to the LSBOC (overlap $=347$ years, $\mathrm{CC}=0.34, t$-value $=6.7)$. The VENMO PINE chronology spans from 2321-2077 BC. Remarkably, the VENMO PINE chronology shows a much higher similarity to the LSBOC than to the oak chronology from the same site (overlap $=144$ years, $\mathrm{CC}=0.09$, $t$-value $=1.1$. Apparently the two species responded differently to the environmental changes at Venner Moor, although the reason for the very low correlation is unclear. Examples of high pine-oak correlations are known from other sites (Pilcher et al., 1995; Chambers et al., 1997; Leuschner et al., 2007). However, also Lageard et al. (1999) found no significant cross-match between contemporaneous oak and pine chronologies from White Moss, Cheshire.

The pine samples show a clear division into two generations separated by a clear GDO phase centred on the year 2168 BC. Compared to the pine samples, the oak samples reach further back in time and show a more even temporal distribution. However, a weak GDO phase around 2300 BC can be recognised, which coincides with the germination phase of the first pine population (Figure 4).

Table 1 Number of dendrochronologically investigated pine and oak samples and statistical features of the tree-ring series. TRW - tree-ring width

\begin{tabular}{|c|c|c|c|c|c|c|c|c|}
\hline \multirow[t]{2}{*}{ Species } & \multirow[t]{2}{*}{ Total } & \multirow[t]{2}{*}{ Dated } & \multicolumn{3}{|c|}{ Tree age (dated trees) in years } & \multirow[t]{2}{*}{ Mean TRW in mm/year } & \multirow[t]{2}{*}{ Mean sensitivity } & \multirow[t]{2}{*}{ Mean auto-corr. } \\
\hline & & & Mean & Min. & Max. & & & \\
\hline Pine & 263 & 224 & 89 & 35 & 154 & 1.22 & 0.38 & 0.76 \\
\hline Oak & 53 & 53 & 122 & 60 & 195 & 1.22 & 0.22 & 0.74 \\
\hline
\end{tabular}




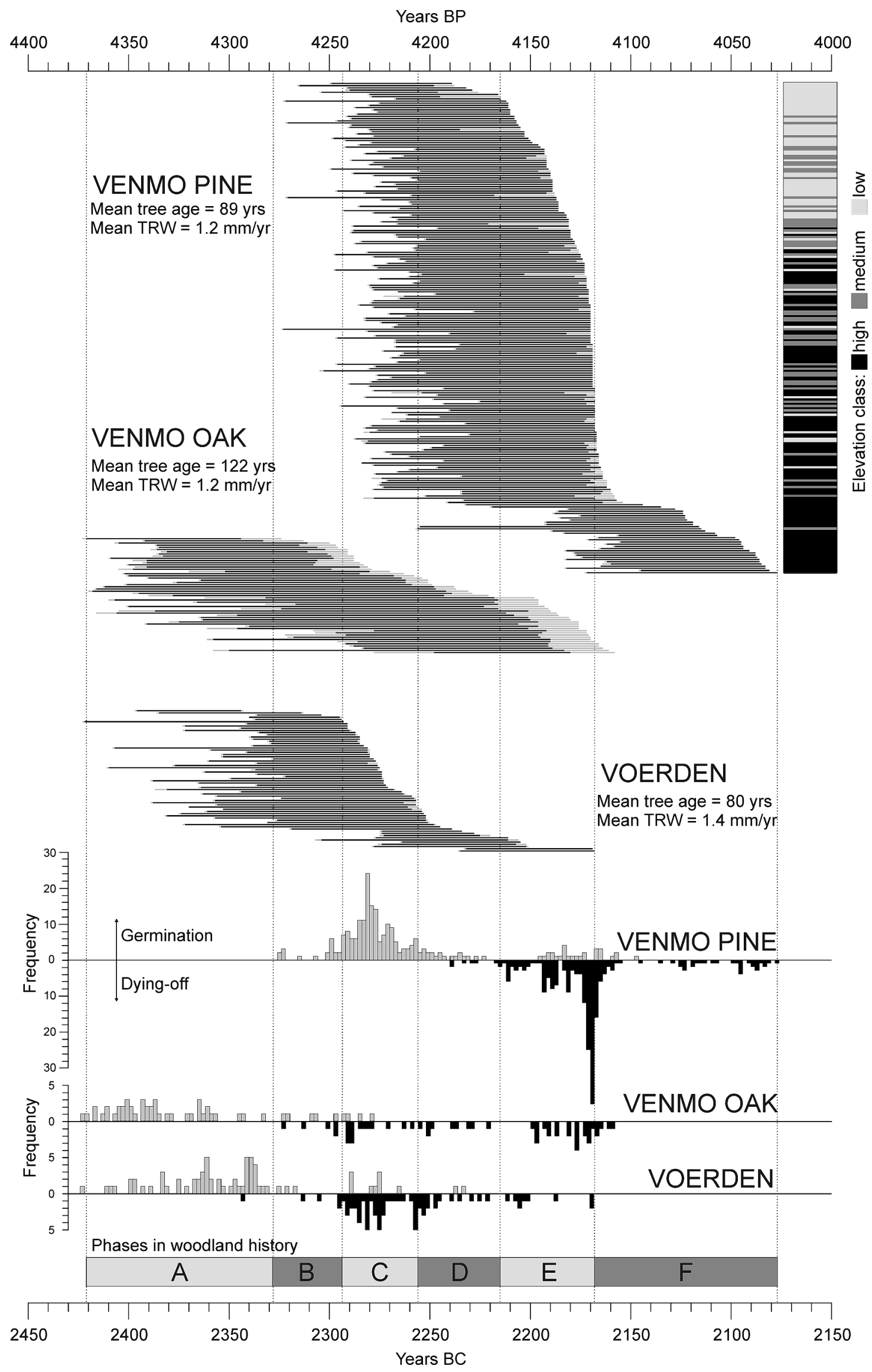

Figure 4 Lifespan (horizontal bars) of subfossil pines and oaks from Venner Moor (VENMO PINE, VENMO OAK), as well as of contemporary pines from Voerdener Moor (VOERDEN) arranged by dying-off date. Grey parts of tree-ring series (horizontal bars) indicate estimated rings to pith and wavey edge. Short bars on the right (elevation class) indicate whether the pines originate from low (light grey), medium (dark grey) or high (black) elevated areas within the Venner Moor study site (see also Figure 3). Histograms indicate the frequency of germination (grey) and dying-off events (black) in 2-year intervals for the Venner Moor samples, as well as for contemporary pine samples from Voerdener Moor. TRW - tree-ring width 

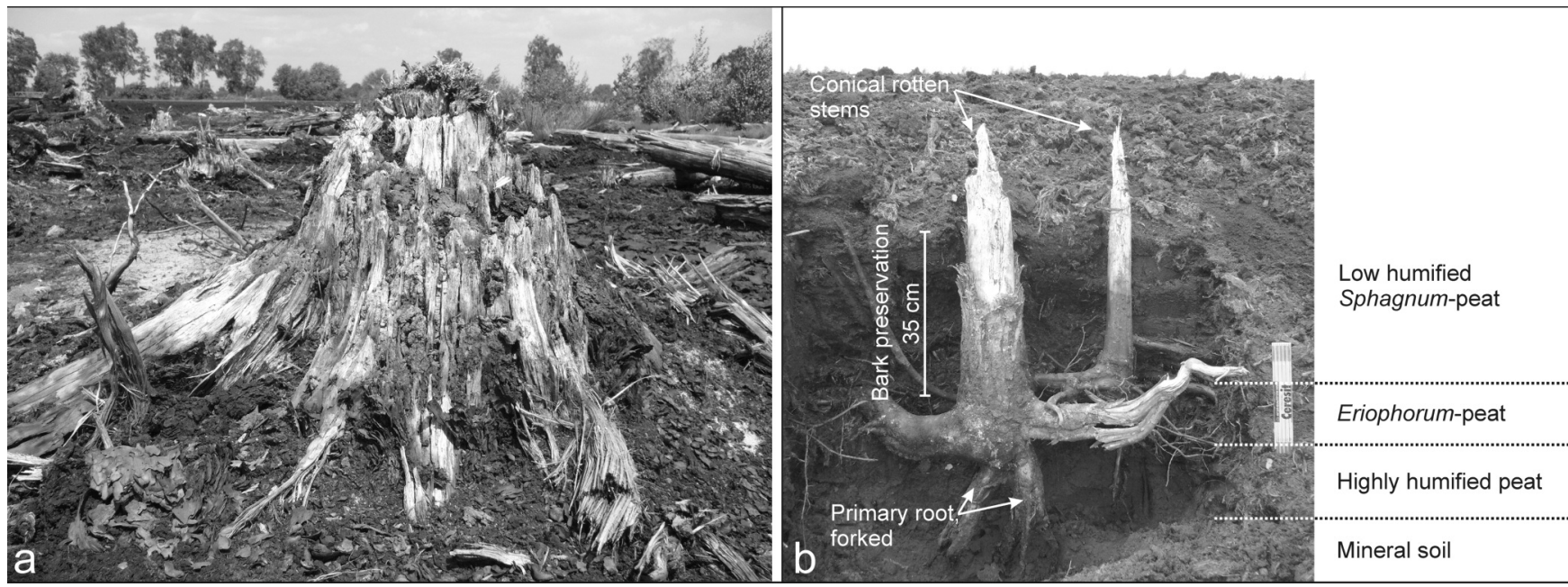

Figure 5 Typical examples of subfossil pine stumps at Venner Moor: (a) heavily rotten and rooting in the mineral soil from areas with high elevations (pine group HIGH) and (b) with high stem preservation, horizontal root plate and weak primary root in area with low mineral soil elevation (pine group LOW)

\section{Spatial and temporal differences in tree growth and preservation}

Among the pine stumps there are obvious differences in growth pattern, root morphology and preservation with respect to their location (Figure 3) and age (Figure 4). Three main groups of samples can be recognised: pine group LOW - trees of the older generation at low elevations (44.4-44.7 m a.s.1.); pine group HIGH - trees of the older generation at high elevations (above $44.9 \mathrm{~m}$ a.s.1.); pine group YOUNG - trees of the younger generation. Intermediate growth forms between group LOW and HIGH were found at intermediate elevations of the mineral soil.

Group LOW is characterised by small stems (mainly $<20 \mathrm{~cm}$ in diameter), which are well preserved with an intact surface and the preservation of bark up to $50 \mathrm{~cm}$ stem height and conical rotten stem tips. The root systems comprise horizontal roots in all directions (root plate) as well as slender primary roots, which reach a depth of up to $40 \mathrm{~cm}$ (Figure 5b). The mean sensitivity of the TRS is very high (Figures 6 and 7). By contrast, the contemporary pines of group HIGH are preserved as much larger stumps (up to $50 \mathrm{~cm}$ in diameter), with a rotten surface down to stem base (Figure 5a). These trees rooted directly on the mineral soil with a bush-like, deep reaching (minimum $50 \mathrm{~cm}$ ) root system (Figure 3). While the samples in group LOW show a sensitive TRS with high inter-annual variability, the TRS in group HIGH shows complacency and low variability (Figure 6, Figure 7). Pines from the younger generation, group YOUNG, occur only at high elevations (Figure 3, map) and have similar characteristics as group LOW, such as small, good preserved stems, horizontal root systems and highly sensitive TRS. In this setting, sensitive TRS are interpreted to represent stress from a fluctuating high water level initially at lower elevations but subsequently also at higher elevations. During the latter phase, pine growth was no longer possible at lower elevations.

All tree remains were examined for signs of fire or storms, in order to evaluate the impact of these disturbances on the woodland dynamics. Within the study area we could not find a single fire scar or tree remains with burned outer surfaces. Only 2 out of ca. 500 trees were preserved in a position clearly suggesting that the tree was uprooted. The original orientation of pine and oak trunks could not be recorded due to displacements during the peat excavation. However, the often evenly rotted surface of lying trunks suggests that these trees fell as dead trees. This interpretation is supported by the observation that most preserved trunks were broken-off from the stump, whereas wind thrown trees would be

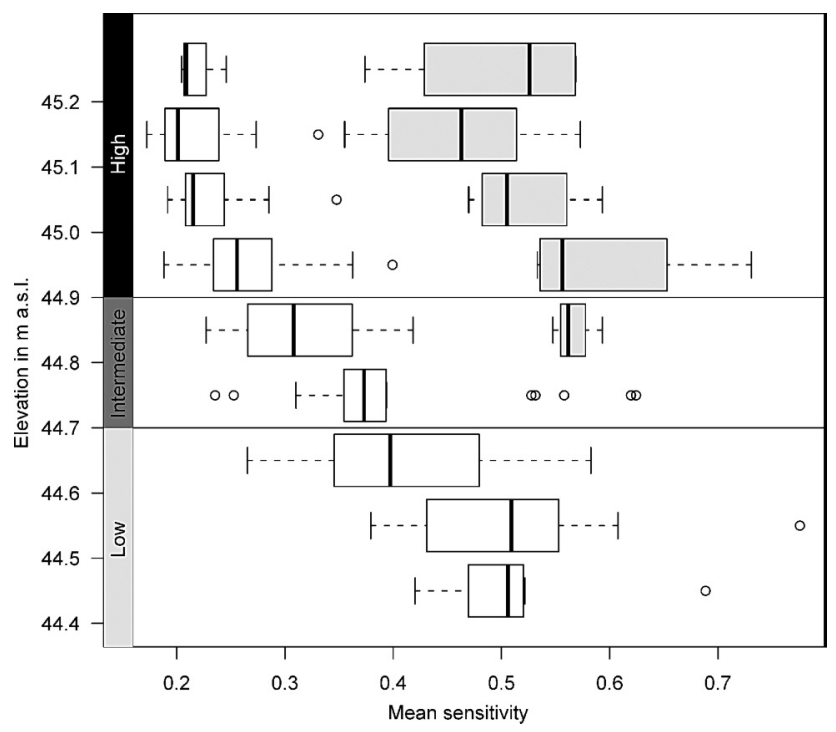

Figure 6 Boxplots of mean sensitivity of pine tree-ring series grouped according to mineral soil elevation at the Venner Moor study site. Open boxes represent the first and filled boxed the second pine generation. The elevational limits for sample groups LOW and HIGH are indicated (see also Figures 3 and 7)

expected to be uprooted. All these observations indicate that fire and storm events were irrelevant for pine and oak population dynamics at Venner Moor.

\section{Pollen analysis}

Pollen analysis was carried out on a monolith covering the lower $63 \mathrm{~cm}$ of peat within the area where the tree remains were uncovered (Figure 3), to obtain a better insight into the on-site development. The pollen diagram (Figure 8) shows Corylus and Alnus as the two most abundant pollen types throughout the profile and also other tree pollen types show only little change in abundance. However, the changing proportion of herb and heather pollen show a clear division of the diagram, which corresponds to a major change in peat stratigraphy at $51 \mathrm{~cm}$ depth.

Samples from the lowermost $12 \mathrm{~cm}$ (VEN-1) contain high values of Ericaceae (mainly Calluna vulgaris and Vaccinium-type) and Melampyrum pollen, which are interpreted to have grown on site and were therefore not included in the main pollen sum. 


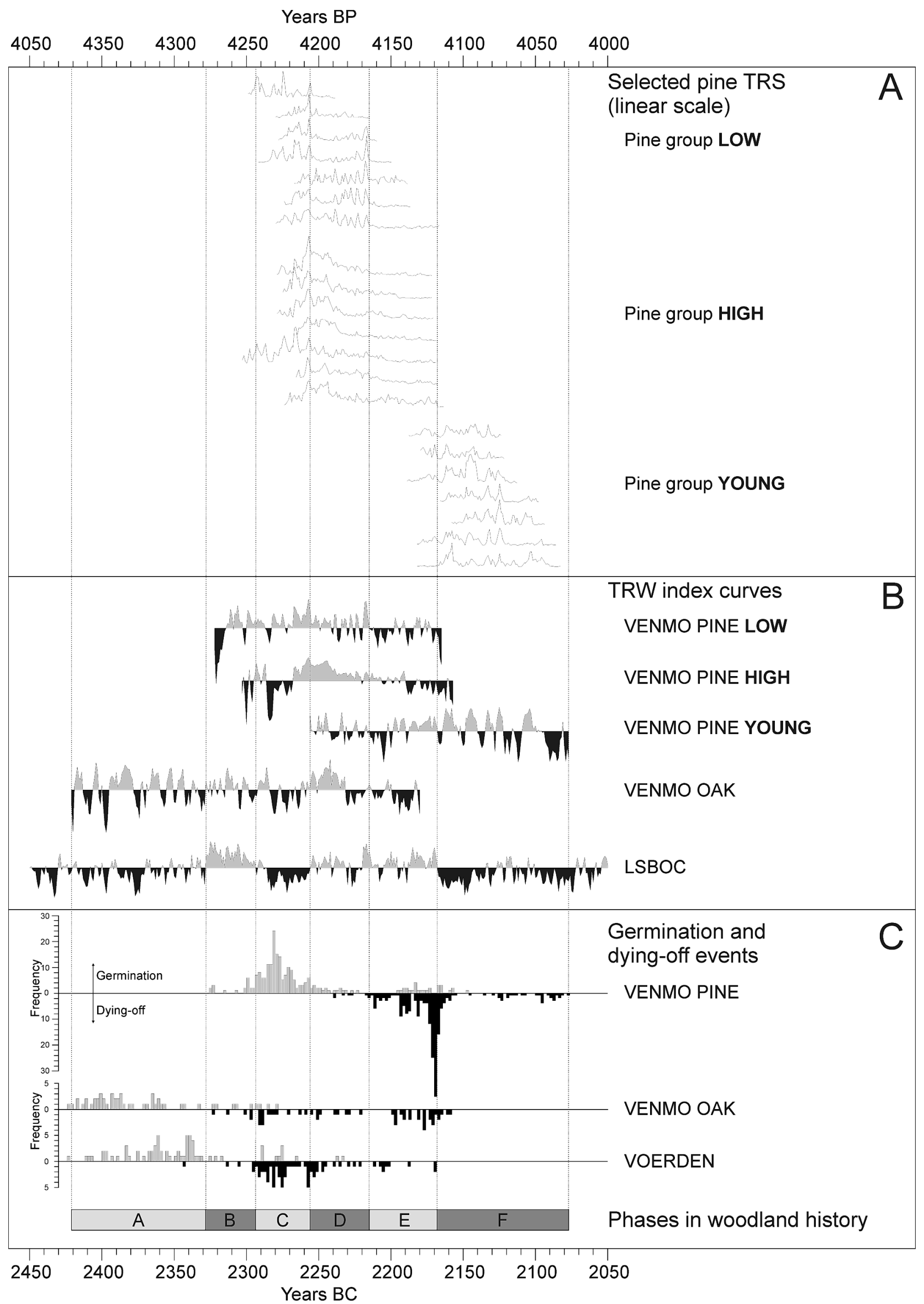

Figure 7 Ring-width variations: (A) selected tree-ring series in linear scale; (B) index chronologies of pines and oaks from Venner Moor (VENMO PINE, VENMO OAK) compared with the regional oak chronology (LSBOC). Index chronologies are coloured grey and black for areas above and below mean, respectively; (C) Frequency of germination (grey) and dying-off events (black) in 2-year intervals for the Venner Moor samples, as well as for contemporary pine samples from Voerdener Moor (VOERDEN). TRS - tree-ring series, TRW - tree-ring width 


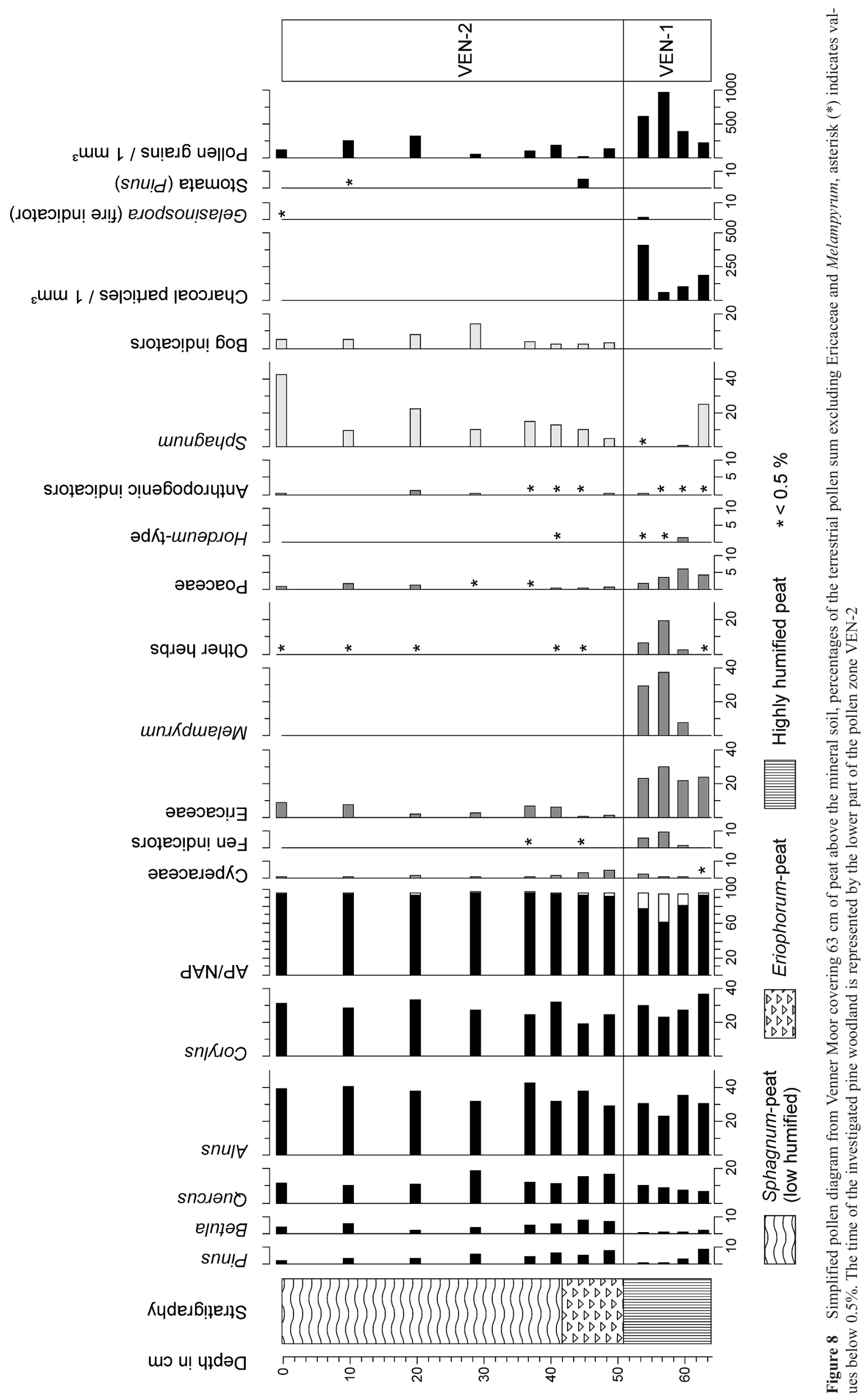


The local occurrence of Calluna and Erica is confirmed by their macrofossils in the peat. Pollen from Solanum dulcamara, Lythrum and Mentha-type indicate locally wet conditions. The zone is also characterised by relatively high values of Poaceae and the occurrence of Hordeum-type pollen with maximums of 6.5 and $1.7 \%$, respectively, in the same sample. In this context, the occurrence of Hordeum-type pollen cannot be used as an indication of human cultivation, as this pollen type includes grasses such as Glyceria fluitans, which could have occurred in the wet habitat characterised by the above described species. Nevertheless, human land-use cannot be ruled out and the high charcoal concentrations could be interpreted as originating from humaninduced fires.

Although the general tree pollen composition changes little throughout the pollen diagram, the local site conditions must have changed dramatically. The upper part of the pollen diagram (VEN-2) shows abundant Sphagnum spores and the occurrence of testate rhizopods such as Amphitrema and Assulina, which are clear indicators of raised bog environments (Figure 8, included in "bog indicators"). On the other hand, pollen types from fen species are absent, which together with the former observations indicates the initiation and growth of a raised bog. The pollen proportions of Pinus and Betula pollen increase across the transition, but especially Pinus pollen proportions decline towards the top of the monolith.

Eriophorum vaginatum and wood remains characterised the peat section between 51 and $42 \mathrm{~cm}$, while the upper $42 \mathrm{~cm}$ consist of a little humified Sphagnum-peat without wood. Thus the section from 51-42 cm represents a transition to ombrotrophic conditions. The increased proportion of Pinus pollen and the find of Pinus stomata in samples from this section indicate the local growth of the tree on the mire at this time. Thus, the growth of at least the older Pinus population occurred probably during this transitional stage in the bog development.

\section{Water table changes and the transition to bog formation}

There are several observations that allow conclusions about water level changes. Many pine trees from low elevations (Figures 3 and 5 b) had a deep reaching primary root but were preserved to considerable stem heights in raised bog peat with low humification. This indicates first a low water table, enabling the development of vertical roots, and later a much higher water table, which allowed the rapid formation of Sphagnum-peat. The age-comparison between stems and primary roots showed that the water table rise started already during the lifetime of the trees, since the growth of the vertical roots ended in average 22 years before the death of the tree. Another observation is that the rooting depth of some pine trees at the southern end of the study area (Figure 3) varied considerably subject to the germination date (Eckstein et al., 2009). An early germinated tree $(2297 \mathrm{BC})$ developed a $40 \mathrm{~cm}$ deep reaching primary root, whereas a nearby tree that germinated 32 years later $(2265 \mathrm{BC})$ had only horizontal roots and a bended stem indicating a high water table and unstable soil conditions. This documents a rising water level in the period from 2297-2265 BC.

Only a rapidly growing Sphagnum-carpet that quickly covers the wood leads to a perfect preservation of pine stumps with attached bark (Kokkonen, 1923; Hayen, 1960, 1969; Leuschner et al., 2007), which is present in the pine sample groups LOW and YOUNG. The start of rapid raised bog growth can thus be dated by the occurrence of tree remains of excellent preservation. The very well preserved pine stumps from areas with low mineral soil elevations (group LOW, Figures 3 and 5b) started to die in 2215 BC (Figure 4), indicating a raised water table and Sphagnum growth at lower elevations already at this time (woodland phase E).
At higher elevations (Figure 3), pines of the first woodland generation (group HIGH) died off later and were not as well preserved, suggesting that Sphagnum overgrowth was not immediate (Figure 5a). However, the well preserved roots and the death of the trees indicate a water level rise to the top of the relief before 2170 BC. Pronounced Sphagnum growth at higher elevations commenced by $2130 \mathrm{BC}$, as can be inferred from the preservation of the second pine generation (pine group YOUNG). It also preserved the partly rotten stumps of the first pine generation at high elevations (group HIGH, Figure 5a).

\section{Reconstruction of the woodland and mire history}

The environmental changes at Venner Moor can be reconstructed in a high temporal and spatial resolution by using the changes in growth pattern and population dynamics of the pines and oaks (Figure 9). We compare these local results to a nearby contemporaneous pine woodland (Voerdener Moor) and with ring-width variations of the LSBOC, in order to evaluate internal (succession) and external factors (climate) as drivers for the reconstructed changes. The oak trees that make up the LSBOC grew on mires and thus water table fluctuations were probably the most important parameter influencing their growth, and growth depressions can thus give an indication of wet and growth release of dry conditions. The combined dataset indicates the following stepwise phases A-G (Figure 7) of the mire- and woodland history at Venner Moor. The discrimination of the phases is based on major changes in the population dynamics of the Venner Moor pines and mayor shifts in the TRW chronologies. Figure 9 shows the development as a spatial-temporal scenario:

\section{A Pre-pine-forest phase before 2328 BC}

Pollen analysis and peat stratigraphy provide information on the nature of the landscape before the initiation of the Pinus woodland on the site. The abundance of Alnus pollen in all samples is indicating the persistence of an alder carr or swamp forest in close proximity throughout the investigated period. Together with some investigated oak trunks, remains of alder, birch and poplar trees were encountered in one part of the study site. Based on the pollen analytical evidence, it is difficult to interpret how the first initiation of a fen peat developed. The fen peat itself accumulated below a wet heath land, which existed in a locally open situation, but not far away from the forest edge. However, whether the forest was locally removed by human activity or the trees disappeared because the site was episodically flooded, remains inconclusive. The presence of Neolithic people in the area is documented as far back as $4800 \mathrm{BC}$ by a number of trackways found $3 \mathrm{~km}$ north of the study site (Bauerochse, 2003; Metzler, 2003). Oak trees established at this time at Venner Moor on higher ground and a population of pine trees established at the nearby Voerdener Moor. However, the lower elevations at Venner Moor remained open due to water level fluctuations and natural fires or through human land use. Until the end of phase A, the LSBOC shows a long-term growth depression.

\section{B The germination of the first pine trees 2328-2294 BC}

The first few pine trees established during a time when at Voerdener Moor almost no germination or dying-off events occurred, which in this context indicates stable growth conditions. The LSBOC shows a long-term growth release, which started abruptly with the beginning of phase $\mathrm{B}$ and lasted throughout this phase. 

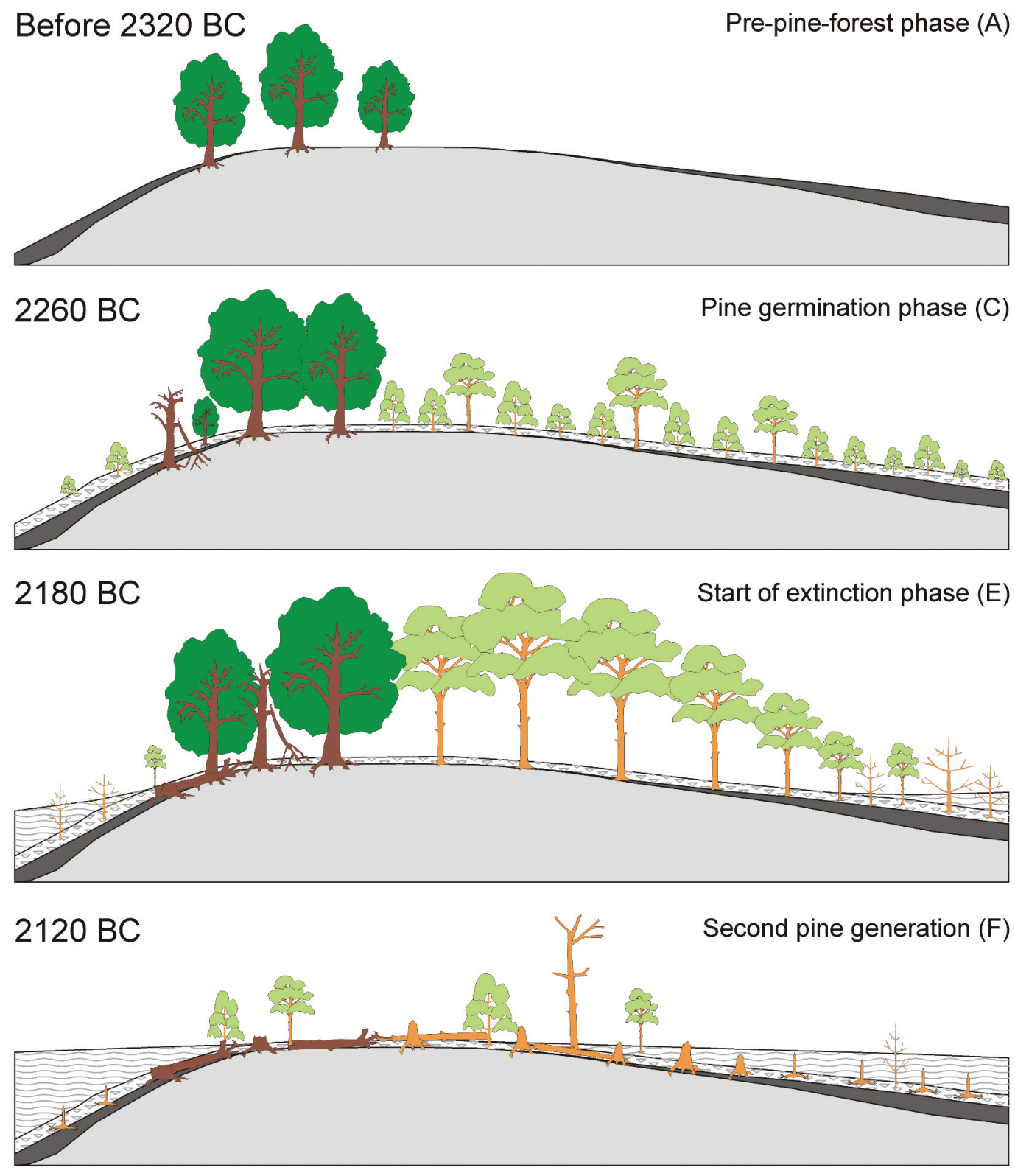

Legend

After 2077 BC

Preservation phase $(\mathrm{G})$
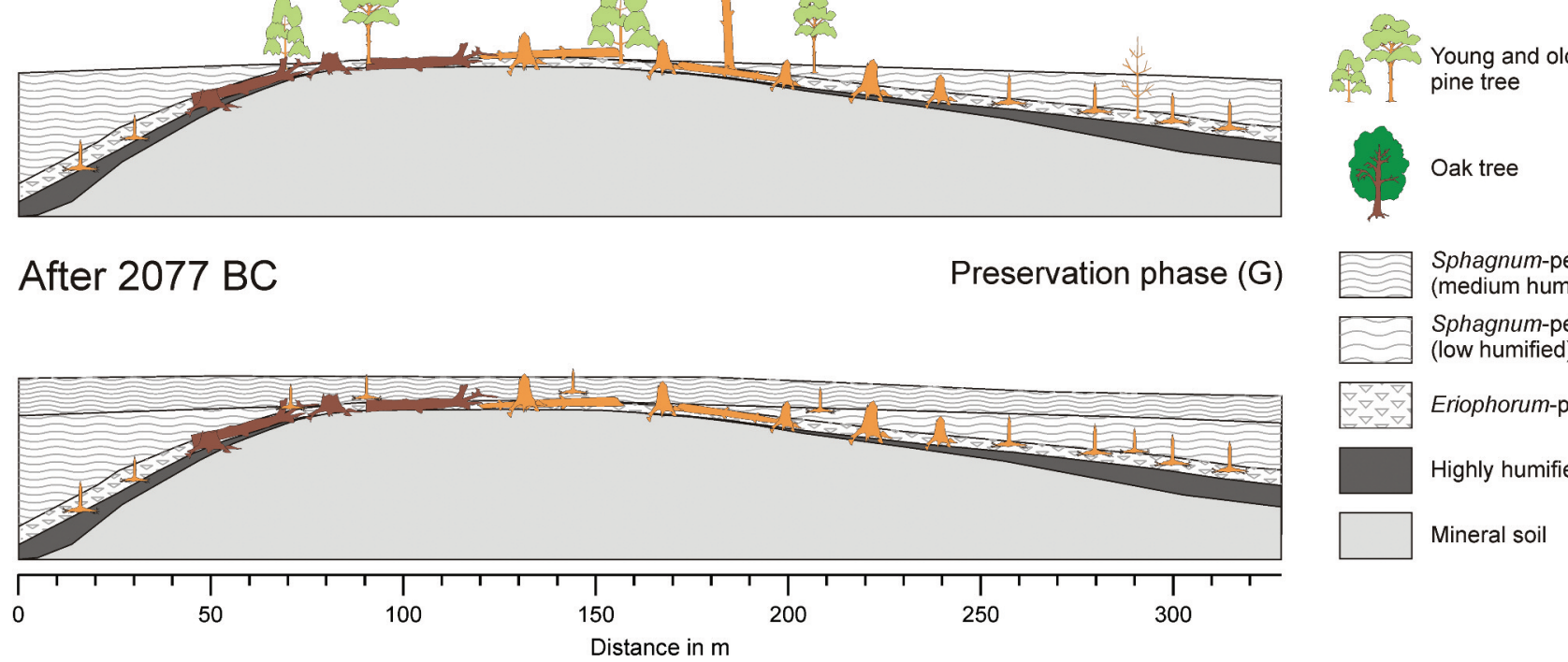

Sphagnum-peat (medium humified)

Sphagnum-peat (low humified)

$\forall \nabla \nabla \nabla \mid$ Eriophorum-peat

Highly humified peat

Mineral soil

Figure 9 Reconstruction of the woodland and mire history at Venner Moor from c. 2400-2050 BC, using the data about population dynamics of pine and oak, tree-ring analyses and peat stratigraphy

\section{Main germination phase of pine 2294-2256 вC}

Population dynamics (Figure 4) and TRS (Figure 7) indicate marked environmental changes. Nearly all pine trees of the first generation germinated. Simultaneously the pine population at Voerdener Moor experienced its main dying-off phase. Some germination as well as dying-off events also occurred in the oak population at Venner Moor. In addition, Eriophorum vaginatum became a dominant species in the study area, indicating the switch to ombrotrophic conditions (Hughes et al., 2000; Rydin and Jeglum, 2006). The change to ombrotrophic conditions is also documented in the pollen diagram (Figure 8). The period covered by this phase coincides with a long-term growth depression in the LSBOC and thus a return to wet conditions, regionally as well as locally. 


\section{Stable woodland phase 2256-2215}

In its initial part, the phase is characterised by a largely undisturbed growth of the pine woodland and above average TRWs. However, around $2240 \mathrm{BC}$ the first few pines were dying and later growth conditions deteriorated for pines and oaks, as indicated by a reduced TRW of the pine and oak chronologies (Figure 7). Incidentally, the pines from low elevations started a cyclic behaviour, with alternating periods of wide and very narrow rings (Figure 7). The LSBOC parallels the TRW of the VENMO OAK and VENMO PINE HIGH chronologies, which show a growth depression after $2240 \mathrm{BC}$. Thus, the whole phase D can be seen as a period with relatively little stress, but with the first signs of unstable conditions in marginal situations.

\section{E Main dying-off phase 2215-2168 вС}

Growth conditions deteriorated in this period, starting with a longterm growth depression of the VENMO PINE LOW chronology at 2215 BC. A depression also occurs in the VENMO PINE HIGH chronology by c. $2190 \mathrm{BC}$. This change within phase E was also mirrored in the course of dying pine trees (Figure 4). Initially the pine trees died at the lowest elevations and only later, during phase $\mathrm{E}$, the pines and oaks from higher elevated areas also died off. The mortality rate reached its peak in the 5 years around $2168 \mathrm{BC}$, when almost all pine trees and all remaining oak trees died. Throughout this phase the LSBOC shows fluctuating but above average ring width. However, exactly at $2168 \mathrm{BC}$, the curve flips and a severe long-term growth depression starts. The preservation state of the pine stumps (good at low and bad at high elevations, Figure 5) indicates intensive raised bog growth in the lower areas. Many trees of the first pine generation developed additional roots that were conspicuously long (up to $5 \mathrm{~m}$ ), thin ( $<2 \mathrm{~cm}$ in diameter) and un-ramified with a horizontal orientation. Such roots are neither suitable for nutrient uptake nor for anchoring in the soil (Eckstein et al., 2009). We interpret them as "seeker roots" developed in nutrient poor and wet conditions. Possibly, a high water level inhibited the further growth of the existing roots and therefore the new "seeker roots" were developed.

\section{F The second pine generation 2168-2077 вС}

Of all the sampled pine trees, only two adult pines survived the dying-off phase around 2168 BC. The majority of the second pine generation were young pines, grown in the under-storey of adult pines and oaks at high elevations (Figure 3 ). These trees reacted during the 2168 event with a severe but only short growth depression. Already five years later they benefited from the ceased competition of the older trees, documented by a growth release reaction (Figure 7). In accordance with the long-term growth depression of the LSBOC, continuing environmental stress can be inferred by the high sensitivity of the tree-ring series (Figures 6 and 7). Also the root and stem morphology indicates very wet site conditions and the good preservation indicates a quickly growing raised bog, at least during the end of phase F. The absence of a second pine generation at the lower elevations corroborates the above interpretation, indicating that lower elevations were already too wet for tree growth.

\section{G Preservation phase after 2077 BC}

With the dying of the last pines, the whole area was covered by raised bog vegetation. The prevailing high water table, and also probably the fast growing peat mosses in this habitat, prevented the re-establishment of trees and facilitated the preservation of all tree remains at Venner Moor. Occasionally very small pine stumps with stem diameter $<2 \mathrm{~cm}$ occurred within the Sphagnum-peat above the investigated pine stump layer. They represent small, short-lived pines growing on the raised bog at some unknown time after the decline of the pine woodland.

\section{Discussion}

The results at Venner Moor clearly indicate that a rising water table is the main factor influencing pine population dynamics, whereas fire and storm events are thought to be largely irrelevant. This supports earlier observations (Kokkonen, 1923; Vomperskij, 1959; Boggie and Miller, 1976; Timmermann, 2003), which also identified the water table as the main factor influencing the growth of mire-rooting pines. At Venner Moor, the influence of a rising water table is most evident in the sequence of dying-off events from low elevations to higher elevations (Figure 4). The deep root systems and complacent TRS of first-generation pines at high elevations indicate locally dry conditions. However, the second pine generation at the same elevations already grew under stress of a high water table and eventually died off because of it. Therefore, this dataset allows changes in the water-table to be tracked over a 200 year period. For the pines of the first generation at low elevations, the rooting depth (Figure $5 \mathrm{~b}$ ) indicates a water-table rise of at least $40 \mathrm{~cm}$ from 2260-2170 BC. Upright stumps with attached bark up to $50 \mathrm{~cm}$ stem height indicate a rapid ( $<50$ years) overgrowth of the lower stem parts by peat mosses after the death of the trees and thus a further water-table rise. At high elevations, the rooting depth of the first pine generation and the preservation characteristics of trees of the second generation indicate a total water-table rise of at least $60 \mathrm{~cm}$ (probably $\sim 1 \mathrm{~m}$ ) in $<200$ years.

During the transition to raised bog formation, the peat surface became increasingly independent from the ground water supply and through the accumulation of peat with a high water storage capacity, an independent bog water table developed. Water-table changes during the early stages of the woodland history were probably due to changes in the ground water table, whereas during the later stages the documented rise can be attributed to the bog water table. It is difficult to determine when exactly this independent bog water table started to exist, but it has certainly played a role since the initiation of extensive Sphagnum growth.

The dendrochronological results presented here can be used to reconstruct this vegetation change in high temporal resolution. The transition to ombrotrophic conditions started with a switch to Eriophorum vaginatum dominated vegetation, which occurred shortly before or synchronous with the establishment of the pines $\sim 2300$ BC (woodland phase B), as indicated by the peat stratigraphy and the pollen diagram (Figure 8). At low elevation, true raised bog conditions started not later than $2215 \mathrm{BC}$, when the trees of the first generation started to die. Thus, the transition to raised bog formation took place in c. 105 years between 2320 and 2215 BC. During this transition decreasing nutrient availability is also documented by the changing morphology of the root systems. At high elevations, the transitional phase is somewhat longer and ends c. $2100 \mathrm{BC}$, with the beginning of the dying-off phase of the second pine generation.

The pine woodland at Venner Moor existed during the transition to a raised bog. This represents a typical phenomenon in northwest German mires, where pine stumps can be seen as a marker layer for the start of the raised bog formation (Leuschner et al., 2007; Bauerochse et al., 2008). The fen-bog transition is often regarded as an autogenic process, mainly influenced by local site conditions rather than by climate variations (Frenzel, 1983; Anderson et al., 2003). If this is true, than phases in the woodland dynamics and stages in mire development should occur at random and independently at different sites. In contrast, the investigations of mire-rooting pines from northwest Germany indicate that climate variability controlled the pine population dynamics (Bauerochse et al., 2006; Eckstein et al., 2009), which is further supported by the results from Venner Moor. Similar to other sites in northwest Germany, the pine population dynamics at Venner Moor can be linked to growth depressions in the regional oak tree-ring series (LSBOC, Figure 7). The LSBOC is 
a regional record, since it comprises tree-ring records of $\sim 120$ subfossil oaks from 18 sites, generally $>100 \mathrm{~km}$ away from Venner Moor (Figure 1). As the oak chronology from Venner Moor is not included, it represents an independent record. The parallels between the regional oak TRW chronology and phases of mire development can be interpreted as both records responding to regional wet and dry shifts.

There is also a striking coincidence between the peak in the dying-off event at $2168 \mathrm{BC}$ and the start of a large-scale growth depression of the LSBOC. This may be explained by the interpretation that the trees at Venner Moor suffered already from a constantly rising water table so that the wet shift at $2168 \mathrm{BC}$ was pushing the already weakened trees over a specific hydrological threshold.

Further evidence of a regional climatic trigger is found in the comparison to population dynamics of subfossil pines from Venner Moor and Voerdener Moor. The main dying-off phase from Voerdener Moor coincides with the Venner Moor germination phase (Figure 7, phase C). In this case, a climatic wet shift around $2280 \mathrm{BC}$ led to the decline of the established pine woodland at Voerdener Moor, whereas it triggered the colonisation of the Venner Moor site by pine. The opposite reactions in the behaviour of these pine populations offer a major contribution to the understanding of the dynamics of mire-rooting pine woodland. In the lowlands of northwest Germany, pine is not able to compete against the broad-leafed trees. Pine cannot regenerate under a dense canopy and therefore depends on disturbances for establishment and regeneration (Dimbleby, 1953; Zackrisson, 1977; Bradshaw and Zackrisson, 1990; Agee, 1998; Hille and den Ouden, 2004). A wet shift causing a dying-off phase can simultaneously trigger a germination phase by creating gaps in the former vegetation, which can be (re-)colonised by pine trees. Thus hydrological disturbance (rise or drop in water table) is an important mechanism for the initial establishment of pine woodlands on wetlands in northwest Germany.

Nearly all root or stump horizons in peat with old enough specimens for dendrochronology, which were encountered so far, are situated at the fen-bog transition (Bauerochse et al., 2008). At Venner Moor we interpret that the initiation of the ombrotrophic bog growth followed the dry pathway with a transitional Eriophorum vaginatum peat possibly connected to a lowered ground water table (Hughes et al., 2000; Hughes and DumaynePeaty, 2002; Hughes and Barber, 2003; Hughes and Barber, 2004). Pine trees are well suited to colonise this new habitat with impoverished nutrient supply and fluctuating water tables, which may be why their remains provide markers for this transition in northwest Germany and possibly elsewhere. Although a pine woodland phase during the fen-bog transition was obviously widespread in northwest Germany (Eckstein et al., 2009), there are many bogs that never experienced pine forestation (Birkholz et al., 1980).

Comparison of the developments at Venner Moor and other European records support the interpretation of climate as the overriding trigger for the population dynamics of mire-rooting pines. Investigations of subfossil pines in England (Lageard et al., 1999; Boswijk et al., 2001) and Ireland (McNally and Doyle, 1984) show a regional pine colonisation phase of mire sites between 2400 and 1900 BC. These records coincide well in time with the pine woodland at Venner Moor, which lasted from 2328-2077 BC and also document a similar climate trend from dry (pine colonisation) to wet (pine decline) conditions. More precise comparisons in time can be made with lake level records from Central Sweden, which are dated by submerged subfossil pine layers in the lakes (Gunnarson et al., 2003; Gunnarson, 2008). Lower than average lake levels were inferred for the period 2400-2200 BC and higher levels for 2200-2100 BC. Thus the lake level rise coincides specifically with the extinction phase at Venner Moor. Precise chronological coincidence is also found with a germination phase of oaks from the Main valley, dating to the same period (2200-2100 BC; Central Germany, Becker and Schirmer, 1977; Leuschner et al., 2000; Spurk et al., 2002). While these germination phases are surely linked to contemporary environmental changes in the floodplain, exact cause and effect relationships are still not fully resolved. Less precisely dated are the high lake level stands between 4159 and $3950 \mathrm{cal}$ BP in the Jura mountains, the northern French Pre-Alps and the Swiss Plateau (Magny, 2004). Also one of the North Atlantic ice-rafted debris events occurred at c. $4200 \mathrm{cal}$ BP (Bond et al., 1997) and thus coincides in time with the woodland phase at Venner Moor. These parallels indicate that a sub-continental wide phase with wetter and cooler than average conditions could have lead to the initiation of the raised bog development and the decline of the pine woodland at Venner Moor, which otherwise could have remained a fen for a long period. Altogether, the dendroecological record of this study documents how relatively short climatic change has a sustained ecological impact on mire habitats.

\section{Conclusions}

Dendroecological investigations of subfossil pine and oak trees have allowed the detailed spatial and temporal reconstruction of the woodland history and mire development during the period from c. 2420-2070 BC at Venner Moor (northwest Germany). The network of sites with dendrochronological investigations of Holocene mire woodlands in northwest Germany shows similar temporal patterns and also links to the Lower Saxonian bog oak chronology LSBOC. Dendroecological investigations from Venner Moor have permitted an improved interpretation of these records and the following two main conclusions can be drawn:

(1) Hydrology is the main factor influencing tree growth and population dynamics in the subfossil, mire-rooting woodlands.

(2) The hydrological changes, which influence the population dynamic of the trees and mire development, are mainly triggered by regional climatic variations, especially wet shifts on the decadal timescale.

Furthermore, this study confirms that shifts to more humid climates can occur abruptly, within a few years. Our results indicate that the sensitive response of mire woodlands to changes in effective precipitation makes these dendro-archives an important and promising proxy record for detailed studies of Holocene humidity fluctuations.

\section{Acknowledgements}

This research is part of a project funded by the German Research Foundation (LE 1805/2-1). We would like to thank Dr B. Birkholz for analysis of peat stratigraphy, V. Platen for surveying and mapping work, B. Leuschner for part of the tree-ring measurements, as well as Frank Schlütz for fruitful discussions. We are especially grateful to R. Zander for information about the tree remains in the first place and for access to the study site.

\section{References}

Agee, J.K. 1998: Fire and pine ecosystems. In Richardson, D.M., editor, Ecology and Biogeography of Pinus, Cambridge: Cambridge University Press, 193-218.

Anderson, R.L., Foster, D.R. and Motzkin, G. 2003: Integrating lateral expansion into models of peatland development in temperate New England. Journal of Ecology 91, 68-76. 
Aniol, R.W. 1983. Tree-ring analysis using CATRAS. Dendrochronologia 1, 45-53.

Baillie, M.G.L. 1982: Tree-ring Dating and Archaeology. Chicago: University of Chicago Press, p. 274.

Baillie, M.G.L. and Pilcher, J.R. 1973: A simple cross-dating program for tree-ring research. Tree-Ring Bulletin 33, 7-14.

Bauerochse, A. 2003: Environmental change and its influence on trackway construction and settlement in the south-western Dümmer area. In Bauerochse, A. and Haßmann, H., editors, Peatlands, Proceedings of the Peatland Conference 2002 in Hannover, Germany, Marie Leidorf, 68-78.

Bauerochse, A., Leuschner, B. and Leuschner, H.H. 2006: Moorhölzer und Archäologie - umweltgeschichtliche und siedlungsarchäologische Befunde. Berichte zur Denkmalpflege in Niedersachsen 26, 40-45.

Bauerochse, A., Caspers, G., Eckstein, J. and Leuschner, H.H. 2008: Ergebnisse und Potenzial dendroökologischer Untersuchungen subfossiler Moorkiefern Nordwestdeutschlands. Telma 38, 55-78.

Becker, B. and Schirmer, W. 1977: Palaeoecological study on the Holocene valley development of the River Main, southern Germany. Boreas 6, 303-21.

Beug, H. 2004: Leitfaden der Pollenbestimmung für Mitteleuropa und angrenzende Gebiete. Pfeil.

Birkholz, B., Schmatzler, E. and Schneekloth, H. 1980: Untersuchungen an niedersächsischen Torflagerstätten zur Beurteilung der abbauwürdigen Torfvorräte und der Schutzwürdigkeit im Hinblick auf deren optimale Nutzung. Hannover: Niedersächsisches Landesverwaltungsamt Naturschutz, Landschaftspflege, Vogelschutz, p. 402.

Boggie, R. and Miller, H.G. 1976: Growth of Pinus contorta at different water-table levels in deep blanket peat. Forestry 49, 123-31. Bond, G., Showers, W., Cheseby, M., Lotti, R., Almasi, P., de Menocal, P., Priore, P., Cullen, H., Hajdas, I. and Bonani, G. 1997: A pervasive millennial-scale cycle in North Atlantic Holocene and glacial climates. Science 278, 1257-66.

Boswijk, G., Whitehouse, N.J., Smith, B.M. and Buckland, P.C. 2001: Thorne Moors (SE 7316). In Bateman, M.D., Buckland, P.C., Frederick, C.D. and Whitehouse, N.J., editors, The Quaternary of East Yorkshire and North Lincolnshire, pp, 169-78.

Bradshaw, R.H.W. and Zackrisson, O. 1990: A two thousand year history of a northern Swedish boreal forest stand. Journal of Vegetation Science 1, 519-28.

Chambers, F.M., Lageard, J.G.A., Boswijk, G., Thomas, P.A., Edwards, K.J. and Hillam, J. 1997: Dating prehistoric bog-fires in northern England to calendar years by long-distance cross-matching of pine chronologies. Journal of Quaternary Science 12, 253-56. DWD 2008: Deutscher Wetter Dienst (DWD), URL: www.dwd.de/. Dimbleby, G.W. 1953: Natural regeneration of pine and birch on the Heather Moors of North-East Yorkshire. Forestry 26, 41-52.

Eckstein, J., Leuschner, H.H., Bauerochse, A. and Sass-Klaassen, U. 2009: Subfossil bog-pine horizons document climate and ecosystem changes during the mid-Holocene. Dendrochronologia 27, $129-46$.

Erdtmann, G. 1960: The acetolysis method. Svensk Botanisk Tidskrift 54, 561-64.

Frenzel, B. 1983: Mires - repositories of climatic information or selfperpetuating ecosystems? In Gore, A.J.P., editor, Ecosystems of the World 4A: Mires: Swamp, Bog, Fen and Moor, Elsevier, 35-65.

Gunnarson, B.E. 2008: Temporal distribution pattern of subfossil pines in central Sweden: perspective on Holocene humidity fluctuations. The Holocene 18, 569-77.

Gunnarson, B.E., Borgmark, A. and Wastegård, S. 2003: Holocene humidity fluctuation in Sweden inferred from dendrochronology and peat stratigraphy. Boreas 32, 347-59.

Hayen, H. 1960: Erhaltungsformen der in den Mooren gefundenen Baumreste. Oldenburger Jahrbuch 59, 21-49, Tafel 9-12.

— 1969: Ein Kiefernwaldhorizont im Südteil des Ipweger Moores (Gemeinde Mooriem, Kreis Wesermarsch). Neue Ausgrabungen und Forschungen in Niedersachsen 4, 329-47.

Hille, M. and Den Ouden, J. 2004: Improved recruitment and early growth of Scots pine (Pinus sylvestris L.) seedlings after fire and soil scarification. European Journal of Forest Research 123, 213-18.

Hughes, P.D.M. and Barber, K. 2003: Mire development across the fen-bog transition on the Teifi floodplain at Tregaron Bog, Ceredigion,
Wales, and a comparison with 13 other raised bogs. Journal of Ecology 91, 253-64

2004: Contrasting pathways to ombrotrophy in three raised bogs from Ireland and Cumbria, England. The Holocene 14, 65-78.

Hughes, P.D.M. and Dumayne-Peaty, L. 2002: Testing theories of mire development using multiple successions at Crymlyn Bog, West Glamorgan, South Wales, UK. Journal of Ecology 90, 456-71.

Hughes, P.D.M., Mauquoy, D., Barber, K. and Langdon, P.G. 2000: Mire-development pathways and palaeoclimatic records from a full Holocene peat archive at Walton Moss, Cumbria, England. The Holocene 10, 465-79.

Iseli, M., Schweingruber, F.H. 1989: Sichtbarmachen von Jahrringen für dendrochronologische Untersuchungen. Dendrochronologia 3, $8-13$

Kokkonen, P. 1923: Beobachtungen über das Wurzelsystem der Kiefer in Moorböden. Acta Forestalia Fennica 25, 1-21.

Lageard, J.G.A., Chambers, F.M. and Thomas, P.A. 1999: Climatic significance of the marginalization of Scotts pine (Pinus sylvestris L.) ca. $2500 \mathrm{BC}$ at White Moss, south Cheshire, UK. The Holocene 9, 321-31.

Leuschner, H.H. 1994: Jahrringanalysen. In Herrmann, B., editor, Archäometrie. Naturwissenschaftliche Analyse von Sachüberresten, Berlin: Springer, 121-35.

Leuschner, H.H. and Schweingruber, F.H. 1996: Dendroökologische Klassifizierung und Auswertung häufig auftretender intraannueller holzanatomischer Merkmale bei Eichen und Kiefern. Dendrochronologia 14, 273-85.

Leuschner, H.H., Delorme, A., Tüxen, J. and Höfle, H.-C. 1985: Eichenstammlagen in Mooren und Talauen und die Klimaverschlechterung im Subboreal. Flora 177, 283-95.

Leuschner, H.H., Delorme, A. and Höfle, H.-C. 1987: Dendrochronological study of oak trunks found in bogs of northwest Germany. Proceedings of the International Symposium on Ecological Aspects of Tree-Ring Analysis, Tarrytown, New York CONF-8608144, 298-318.

Leuschner, H.H., Spurk, M., Baillie, M.G.L. and Jansma, E. 2000: Stand dynamics of prehistoric oak forests derived from dendrochronologically dated subfossil trunks from bogs and riverine sediments in Europe. Geolines 11, 118-21.

Leuschner, H.H., Sass-Klaassen, U., Jansma, E., Baillie, M.G.L. and Spurk, M. 2002: Subfossil European bog oaks: population dynamics and long-term growth depressions as indicators of changes in the Holocene hydro-regime and climate. The Holocene 12, 695-706.

Leuschner, H.H., Bauerochse, A. and Metzler, A. 2007: Environmental change, bog history and human impact around $2900 \mathrm{BC}$ in NW Germany - preliminary results from a dendroecological study of a subfossil pine woodland at Campemoor, Dümmer Basin. Vegetation History and Archaeobotany 16, 183-95.

Magny, M. 2004: Holocene climate variability as reflected by midEuropean lake-level fluctuations and its probable impact on prehistoric human settlements. Quaternary International 113, 65-79.

McNally, A. and Doyle, G.J. 1984: A study of subfossil pine layers in a raised bog complex in the Irish midlands - I. Palaeowoodland extend and Dynamics. Proceedings of the Royal Irish Academy. Series $B$ 84, 57-70.

Metzler, A. 2003: Early Neolithic peatland sites around lake Dümmer. In Bauerochse, A. and Haßmann, H., editors, Peatlands, Proceedings of the Peatland Conference 2002 in Hannover, Germany, Marie Leidorf, 62-67.

Moore, P.D., Webb, J.A. and Collinnson, M.E. 1991: Pollen Analysis, second edition, Blackwell.

Pilcher, J.R., Baillie, M.G.L., Brown, D.M., McCormac, F.G., MacSweeney, P.B. and McLawrence, A.S. 1995: Dendrochronology of subfossil pine in the north of Ireland. Journal of Ecology 83, $665-71$.

Riemer, T. 1994: Über die Varianz von Jahrringbreiten. Statistischen Methoden für die Auswertung der jährlichen Dickenzuwächse von Bäumen unter sich ändernden Lebensbedingungen. $\mathrm{PhD}$ thesis, Berichte des Forschungszentrums Waldökosysteme der Universität Göttingen Reihe A 121.

Rydin, C.H. and Jeglum, J.K. 2006: The Biology of Peatlands. Oxford: Oxford University Press. 
Schweingruber, F.H. 1987: Tree rings: Basics and Applications of Dendrochronology. Dordrecht: Reidel Publishing, p. 276.

Spurk, M., Leuschner, H.H., Baillie, M.G.L., Briffa, K.R. and

Friedrich, M. 2002: Depositional frequency of German subfossil oaks: climatically and non-climatically induced fluctuations in the Holocene. The Holocene 12, 707-15.

Timmermann, T. 2003: Hydrologische Dynamik von Kesselmooren und ihre Bedeutung für die Gehölzentwicklung. Telma 33, 85-107. van Geel, B. and Aptroot, A. 2006: Fossil ascomycetes in Quaternary deposits. Nova Hedwigia 82, 313-30. van Geel, B., Buurman, J., Brinkkemper, O., Schelvis, J., Aptroot, A., van Reenen, G. and Hakbijl, T. 2003: Environmental reconstruction of a Roman Period settlement site in Uitgeest (The Netherlands), with special reference to coprophilous fungi. Journal of Archaeological Science 30, 873-84.

Vomperskij, S.E. 1959: Osobennosti stroenija kornevyh sistem Pinus sylvestris L. na osusennyh torfianich potschwach. Botanicheskiy Zhurnal SSSR 44, 79-87.

Zackrisson, O. 1977: Influence of forest fires on the north Swedish boreal forest. Oikos 29, 22-32. 